\title{
(बR
}

\section{Fahr's Disease and Its Relationship with Hypoparathyroidism: Case Report}

\author{
Fahr Hastalığı ve Hipoparatiroidi ile Olan Illişkisi: Olgu Sunumu
}

\author{
Engin Deniz Arslan, Fevzi Yılmaz, Şükran Koca, Bünyamin Uyanık, Müge Sönmez, Cemil Kavalcı
}

Department of Emergency, Ankara Numune Training and Research Hospital, Ankara, Turkey

\begin{abstract}
Fahr's disease is characterized by a variety of progressive neuropsychological and cognitive symptoms and symmetric basal ganglia calcifications on cranial CT. The related conditions which may cause Fahr's disease are hypoxia, radiation, systemic disorders, toxins, disorders of the parathyroid hormones, aberrant calcium metabolism and encephalitis. In this article, we present a 34-year-old female patient diagnosed with Fahr's disease associated with hypoparathyroidism.
\end{abstract}

Keywords: Fahr's disease, Basal Ganglia calcification, hypoparathyroidism

Received: 07.09.2012 Accepted: 14.11.2012

Available Online Date: 20.05.2013

\section{ÖZET}

Fahr hastalığı çeşitli ilerleyici nöro-psikolojik ve bilişsel belirtilerle seyreden ve kranial BT'de simetrik bazal gangliyon kalsifikasyonu ile karakterize bir hastalıktır. Fahr hastalığı'nın hipoksi, radyasyon, sistemik hastalıklar, toksinler, paratiroid hormon ve kalsiyum metabolizması ve ensefalitler ile bağlantılı olduğu ileri sürülmüştür. Bu yazıda hipoparatiroidi ile ilişkili Fahr hastalığı tanısı konan 34 yaşındaki kadın hasta sunuldu.

Anahtar Kelimeler: Fahr hastalığı, Bazal Ganglion kalsifikasyonu, hipoparatroidizm

Geliş Tarihi: 07.09.2012 Kabul Tarihi: 14.11.2012

Çevrimiçi Yayın Tarihi: 20.05.2013

\section{Introduction}

Fahr's disease (FD) is characterized by various types of progressive neurophysical and cognitive symptoms and symmetric basal ganglia calcifications on cranial CT. The disease is also known as idiopathic basal ganglia calcification (IBGC) (1). The disease can be seen either sporadically or with familial inheritance. The clinical and radiological picture of the disease is also associated with disorders of the parathyroid hormones and calcium metabolism, as well as toxins, encephalitis and hypoxia. In this article, we present a 34-year-old female patient with FD associated with hypoparathyroidism (1, 2).

\section{Case Report}

A 34-year-old female presented with numbness on her tongue and arms and a transient loss of consciousness a few hours previously. She mentioned intermittent episodes of numbness, weakness, tremor, sleep disorders and transient loss of consciousness for several months. She also complained of concurrent weight loss. Her physical examination revealed ataxia, tremors and the Chvostek sign at presentation. Laboratory investigations showed normal limits of whole blood counts, renal function tests and thyroid hormones. Serum calcium ( $6 \mathrm{mg} / \mathrm{dL}$ ), ionized calcium $(3.06 \mathrm{mg} / \mathrm{dL})$ and parathyroid hormone levels $(0.6 \mathrm{pmol} / \mathrm{L})$ were decreased and phosphorus $(7.3 \mathrm{mg} / \mathrm{dL}$ ) was higher than normal. Her cranial CT showed bilateral symmetric calcifications in the caudate and lentiform nuclei, thalamus and cerebral gyrus as shown in Figure 1 and 2. The patient was consulted by a neurologist for a probable seizure and the patient was treated with an intravenous calcium infusion followed by per oral supplemental calcium and calcitriol, then referred to the endocrinology and neurology departments.

\section{Discussion}

Intracranial calcifications normally occur in about $0.3-1.5 \%$ of individuals without any symptoms. In FD, patients have progressive neurophysicial, cognitive and psychiatric abnormalities alone or in combination with symmetric calcifications of the basal 


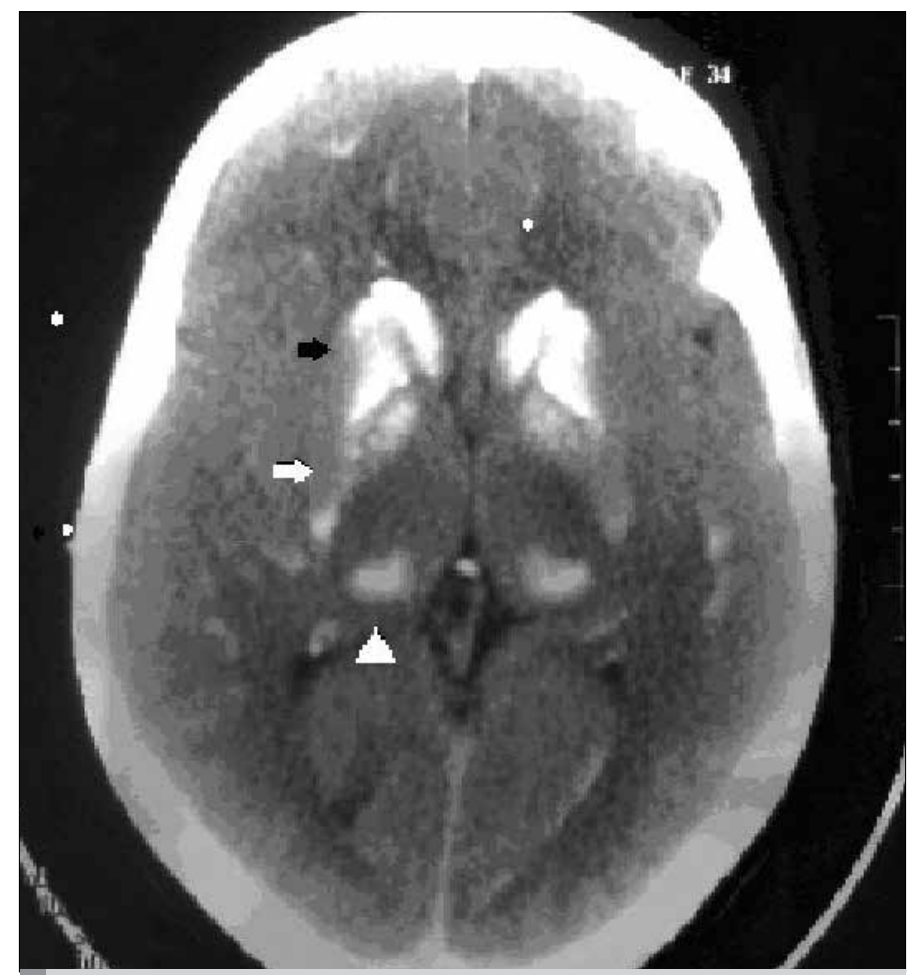

Figure 1. Black arrow: Calcifications in nucleus caudatus, White arrow: Calcifications in lenticular nucleus.

Arrow head: Calcifications in thalamus

ganglia; this is also referred to as idiopathic symmetric basal ganglia calcification (2). Many terms have been used to describe this entity, with the most popular name as Fahr's disease. The entity may be either sporadic or familial. The familial types of FD are most commonly reported as being due to autosomal dominant or rarely autosomal recessive inheritance $(3,4)$.

In FD, basal ganglia calcifications may be seen secondary to infectious, metabolic and genetic diseases $(5,6)$. The most common metabolic disorders that cause to FD are parathyroid hormone and calcium abnormalities. Although hypoparathyroidism, pseudohypoparathyroidism and hyperparathyroidism are both associated with FD, hypoparathyroidism and hypocalcaemia are the most commonly reported disorders. Acquired hypoparathyroidism may be seen due to iatrogenic causes such as surgery, autoimmune diseases, infiltrative diseases and neck irradiation. In our case, the patient had no identifiable cause of acquired hypoparathyroidism and had no family history indicating the familial form; we suspected sporadic late onset hypoparathyroidism.

In FD, the onset of symptoms occurs between 30 and 60 years of age with gradual progression of neuropsychiatric and movement disorders. Spasticity, gait disturbances, cognitive impairment, headache, vertigo, seizures and dementia are the other clinical manifestations of the disease. However, patients may also be asymptomatic.

Diagnosis is made using imaging tools and cranial CT is the preferred method. The calcifications are easily recognized as hyperdense le-

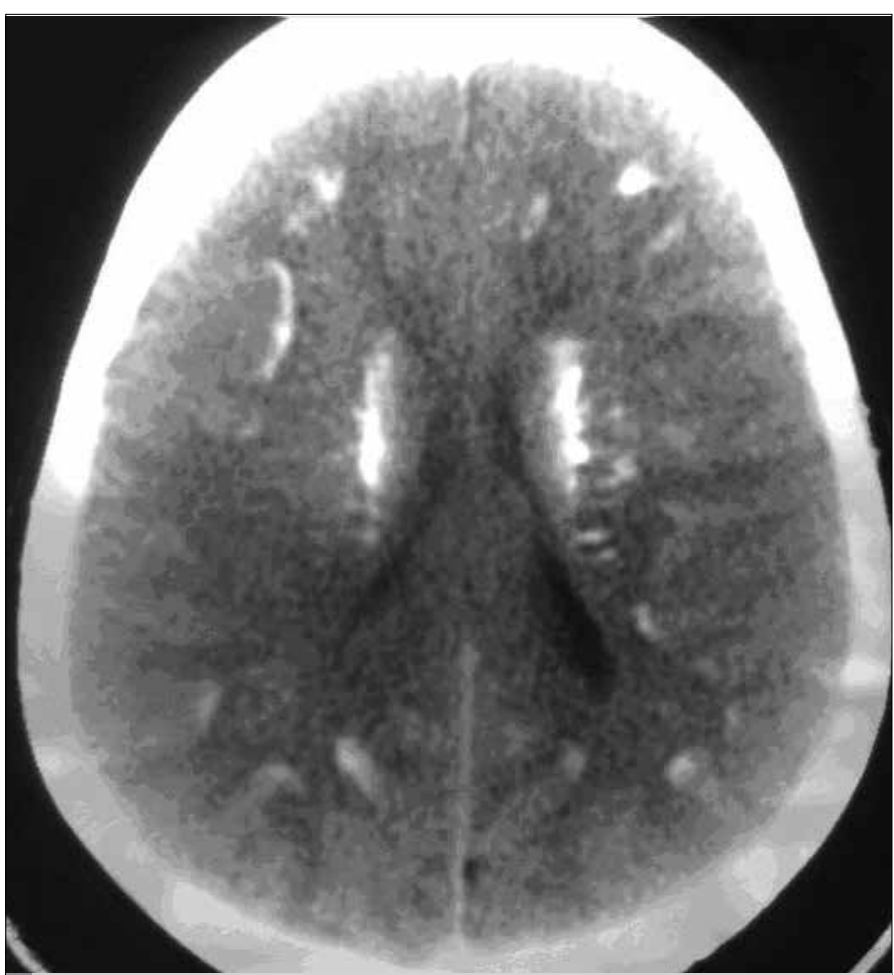

Figure 2. Calcifications in cerebral gyri

sions, and the most common site of calcification is the lenticular nucleus, particularly the globus pallidus. Involvement of other sites of the basal ganglia are also common. The calcifications seem to be symmetric and progressive. The reason for the focal accumulation of calcium in the basal ganglia is not well-understood. Manyam et al. (7) measured the total volume of calcifications and found a significantly greater amount of calcification in symptomatic patients compared to asymptomatic patients. $T_{2}$ weighted MRI images detect hyperintensities that may reflect a slowly progressive, metabolic or inflammatory process in the brain which subsequently calcifies (8).

The pathophysiology of this condition is not well-defined, so there is no treatment recommendation and the prognosis is hard to predict. However, there are some reports of FD secondary to hypoparathyroidism in which calcium and phosphorus metabolism was corrected, leading to considerable improvement (9).

In FD, cranial CT may be misinterpreted by an inexperienced physician as hemorrhagic stroke that does not correlate with physical examination. Patients with hemorrhagic lesions in the basal ganglia or internal capsule are more likely to be in a coma and present with hypotonia and flaccid paralysis; however, in FD, spasticity, gait disturbances and involuntary movements are more prominent.

\section{Conclusion}

Although FD was defined years ago, it may be still unrecognized in clinical practice because of the rarity of the entity. The emergency physician must be aware of this condition, particularly in patients with neuropsychiatric symptoms and disorders in calcium and 
phosphorus metabolism. Also, for patients with IBGC, genetic counseling may play an important role for subsequent generations.

\section{Conflict of Interest}

No conflict of interest was declared by the authors.

Peer-review: Externally peer-reviewed.

\section{Author Contributions}

Concept - E.D.A., F.Y.; Design - S..K., M.S.; Supervision - B.U., C.K.; Literature Review - E.D.A.; Writer - E.D.A.; Critical Review - F.Y., M.S.

\section{Çıkar Çatışması}

Yazarlar herhangi bir çıkar çatışması bildirmemişlerdir.

Hakem değerlendirmesi: Dış bağımsız.

\section{Yazar Katkıları}

Fikir - E.D.A., F.Y.; Tasarım - Ş.K., M.S.; Denetleme - B.U., C.K.; Literatür taraması - E.D.A.; Yazıyı yazan - E.D.A.; Eleştirel İnceleme - F.Y., M.S.

\section{References}

1. Koçak S, Erdemir E, Bayrak A, Kara H, Gül M. Fahr's Disease: Two Cases Report. JAEM 2009; 8: 46-9.

2. Hoque MA, Siddiqui MR, Arafat Y. Fahr's Disease: A Very Rare Cause of Epilepsy. Mymensingh Med J 2010; 19: 127-9.

3. Daniel H. Geschwind, Loginov M. Identification of a Locus on Chromosome 14q for Idiopathic Basal Ganglia Calcification [Fahr Disease]. Am J Hum Genet 1999; 65: 764-72. [CrossRef]

4. Malik R, Pandya VK, Naik D. FAHR Disease - A Rare Neurodegenerative Disorder. Ind J Radiol Imag 2004; 14: 383-4.

5. Verulashvili IV, Glonti LSh, Miminoshvili DK, Maniia MN, Mdivani KS. Basal ganglia calcification: clinical manifestations and diagnostic evaluation. Georgian Med News 2006; 140: 39-43.

6. Sbai H, Smail L, Hamdani S, Essatara Y, Harrandou M, Khatouf M, et al. Fahr syndrome discovered following a bacterial meningitis]. Rev Med Interne 2008; 29: 412-4. [CrossRef]

7. Manyam BV, Walters AS, Narla KR. Bilateral striopallidodentate calcinosis: clinical characteristics of patients seen in a registry. Mov Disord 2001; 16 : 258-64. [CrossRef]

8. Avrahami E, Cohn DF, Feibel M, Tadmor R. MRI demonstration and CT correlation of the brain in patients with idiopathic intracerebral calcification. J Neurol 1994; 241: 381-4. [CrossRef]

9. Şenoğlu M, Tuncel D, Orhan F.Ö, Yuksel Z, Gokçe M. Fahr's Syndrome: A Report of Two Cases Firat Tip Dergisi 2007; 12: 70-2. 